\title{
PENGUATAN PENGETAHUAN TENTANG FAUNA NYAMUK PADA MGMP GURU BIOLOGI SMA
}

\author{
Hebert Adrianto ${ }^{1,2^{*}}$, Sri Subekti ${ }^{3}$, Heny Arwati $^{3}$, Indah S. Tantular ${ }^{3}$, \\ Yuwono Marta Dinata ${ }^{2}$, May Fanny Tanzilia ${ }^{2}$, Wira Widjaya Lindarto ${ }^{2}$, \\ Amadeus Michael Goein ${ }^{4}$, Nathania Disa Ariesta ${ }^{4}$ \\ ${ }^{1}$ Program Doktor, Universitas Airlangga, Surabaya \\ ${ }^{2}$ Universitas Ciputra, Surabaya \\ ${ }^{3}$ Universitas Airlangga, Surabaya \\ ${ }^{4}$ RSUD Dr. M. Soewandhie-Universitas Ciputra, Surabaya \\ Email: hebert.data@gmail.com

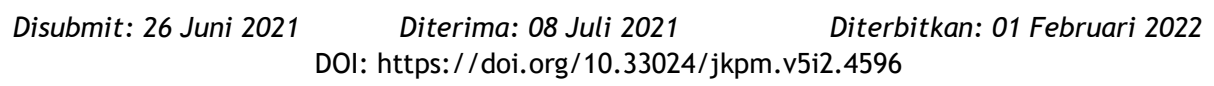

\begin{abstract}
ABSTRAK
Penyakit Demam Berdarah Dengue (DBD) menimbulkan sakit sehingga menghentikan produktivitas manusia, kematian, bahkan wabah (Kejadian Luar Biasa/ KLB). DBD ditularkan melalui perantaraan nyamuk. Tujuan kegiatan pengabdian masyarakat ini adalah memberikan penguatan materi kepada para guru tentang bahaya dan kewaspadaan terhadap nyamuk. Kegiatan ini dilaksanakan secara daring menggunakan zoom. Peserta kegiatan ini adalah semua guru mata pelajaran Biologi yang tergabung di dalam MGMP Biologi SMA Kabupaten Sidoarjo. Instrumen yang digunakan adalah laptop, materi presentasi format ppt, zoom, dan google form. Hasil kegiatan adalah kegiatan berjalan dengan lancar. Ada peningkatan pengetahuan para peserta dari dimana rata-rata nilai pre test $=53$ dan post test $=81$.
\end{abstract}

Kata Kunci: Nyamuk, guru, pengetahuan

\begin{abstract}
Dengue hemorrhagic fever (DHF) causes pain that stops human productivity, death, even plague. DHF is transmitted through mosquito intercession. This community service activities aims to provide material reinforcement to teachers about the dangers and vigilance against mosquitoes. This activity is carried out online using zoom. Participants of this activity are all teachers of Biology subjects who are members of MGMP Biology SMA Sidoarjo. The instruments used are laptop, ppt format presentation material, zoom, and google form. The result of the activity is that the training runs smoothly. There was an increase in the participants' knowledge from which the average pre-test value $=53$ and post-test $=81$.
\end{abstract}

Keywords: Mosquitoes, teachers, knowledge 


\section{PENDAHULUAN}

Penyakit Demam Berdarah Dengue (DBD) adalah salah satu penyakit tular vektor yang masih menjadi problem kesehatan di yang dihadapi oleh negara tropis termasuk endemis di negara Indonesia sampai saat ini. Penyakit DBD menimbulkan kesakitan sehingga melumpuhkan produktivitas manusia, kematian, bahkan wabah (Kejadian Luar Biasa/ KLB). Indonesia pernah menempati peringkat ke dua di dunia dan tertinggi di Asia Tenggara dengan jumlah kasus DBD terbanyak pada tahun 2004 hingga 2010 (Prayitno et al., 2017). Penyakit DBD pertama kali muncul di Indonesia pada tahun 1968, yaitu di kota Jakarta dan Surabaya (Harapan et al., 2019) dan menyebar ke semua provinsi. Penyakit ini muncul setiap tahun setelah musim hujan. Agen penyakit ini adalah virus dengue (kelompok arbovirus) yang ditularkan melalui perantaraan vektor nyamuk Aedes aegypti dan Aedes albopictus (Pramestuti dan Djati, 2013).

Kemenkes melalui Rencana Aksi Program Kemenkes Pembangunan Kesehatan 2020 - 2024 memprioritaskan pencegahan dan pengendalian untuk menurunkan penyakit vektor (Kemenkes, 2020). Program 3M Plus digalakkan oleh Pemerintah untuk memberantas sarang nyamuk. Konsep $3 \mathrm{M}$ adalah menguras penampungan air, menutup rapat penampungan air, dan memanfaatkan kembali barang bekas yang dapat menampung air. Konsep Plus adalah memelihara ikan pemakan jentik nyamuk, menggunakan obat anti nyamuk, memasang kawat kasa pada jendela dan ventilasi, gotong royong membersihkan lingkungan, memeriksa tempat-tempat penampungan air, meletakkan pakaian bekas pakai dalam wadah tertutup, memberikan larvasida, memperbaiki saluran dan talang air yang tidak lancar, dan menanam tanaman pengusir nyamuk (Kemenkes, 2019). Selain itu tanaman fitotelmata yang dapat menampung air dan menjadi habitat nyamuk bertelur juga perlu diperhatikan (Adrianto, 2021)

Di sisi lain, penyakit DBD juga ditambah lagi dengan munculnya pandemi COVID-19 (Coronavirus Disease 2019) sejak tahun 2020 yang juga menimbulkan krisis di bidang ekonomi, sosial, pendidikan, transportasi, dan sebagainya (Harapan et al., 2020; Lorenz et al., 2020) sehingga akhirnya Indonesia menghadapi beban ganda (burden disease). Kebijakan Pemerintah mewajibkan sekolah dan bekerja dari rumah berpotensi meningkatkan peluang orang-orang di dalam rumah menjadi sumber makanan nyamuk. Di dalam bidang pendidikan, sekolah melalui guru memiliki peran yang sangat vital untuk memberikan edukasi kepada peserta didik tentang kewaspadaan terhadap nyamuk dan pemberantasan sarang nyamuk (PSN) (Roziqin dkk, 2020). Guru memiliki banyak peserta didik yang diajar setiap tahun ajaran baru. Peran guru ini dianggap salah satu cara yang cukup efektif untuk memberikan edukasi, membentuk karakter, dan menjangkau banyak orang khususnya peserta didik dan keluarga. Oleh karenanya pemahaman yang baik mengenai nyamuk, baik perilaku bertelur dan perilaku menghisap darah harus dimiliki oleh guru. Hendri dkk (2020) melaporkan bahwa sosialisasi PSN $3 \mathrm{M}$ plus perlu dilakukan di sekolah untuk meningkatkan pengetahuan dan peran serta siswa dalam pengendalian DBD karena pengetahuan dan tindakan pemberantasan vektor nyamuk DBD pada siswa level pendidikan SMA di wilayah Pangandaran masih rendah. Fauna nyamuk Ae. aegypti menyukai kontainer dan memilih air jernih/ bersih di dalam rumah manusia sebagai tempat bertelur, sedangkan nyamuk Ae. albopictus menyukai kontainer di luar rumah (Pramadani dkk, 2020). 
Guru yang menjadi mitra dalam kegiatan edukasi ini adalah para guru mata pelajara Biologi di Sekolah Menengah Atas baik Negeri, Swasta, maupun Madrasah Aliyah di Kabupaten Sidoarjo. Potensi besar MGMP Biologi SMA seSidoarjo ini adalah memiliki pengurus yang kompak, guru biologi memiliki antusias belajar dan terus mengasah kompetensi diri, dapat mengoperasikan teknologi informasi, dan rutin bertemu setiap bulan. Melalui program kerjasama yang sudah dijalin selama empat tahun, maka kali ini mitra MGMP Biologi SMA se-Sidoarjo mendapatkan penguatan materi tentang serangga nyamuk.

\section{MASALAH}

Kegiatan ini dilakukan sesuai kesepakatan dengan pengurus MGMP Biologi SMA Kabupaten Sidoarjo terkait kebutuhan pembelajaran animalia, situasi pandemi COVID-19 dan ditambah beban kasus Demam Berdarah Dengue (DBD). Pengabdi dan MGMP Biologi SMA Kabupaten Sidoarjo sudah bermitra selama empat tahun. Tujuan khusus dari kegiatan ini adalah memberikan penguatan materi kepada para guru tentang bahaya dan kewaspadaan terhadap nyamuk.

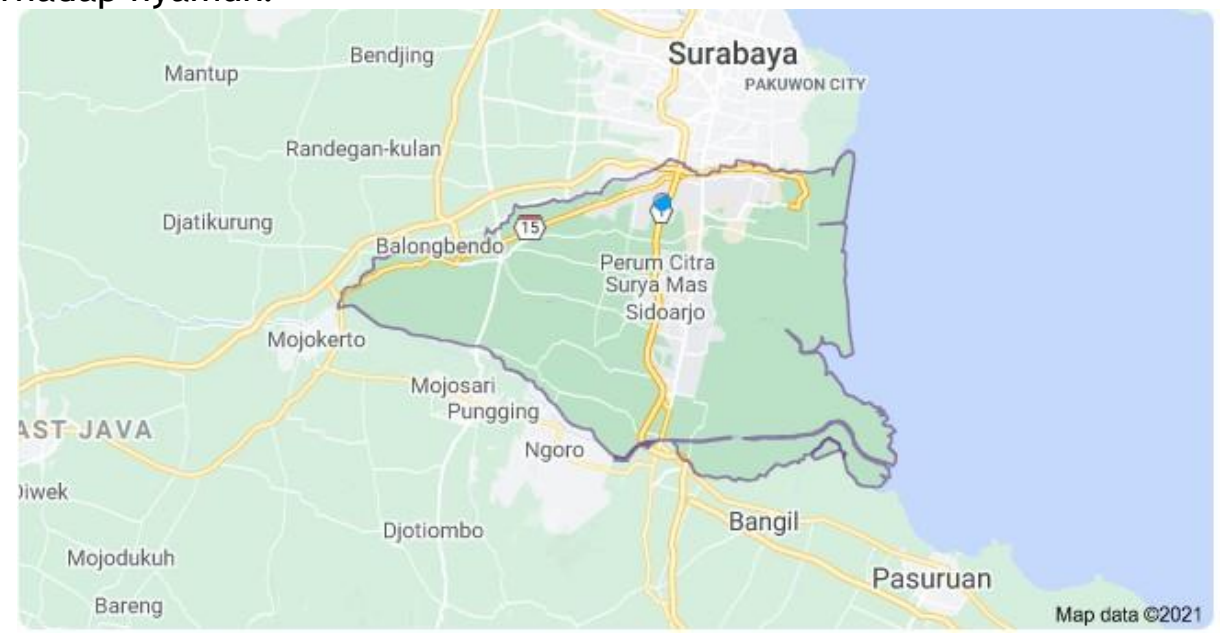

Gambar 1. Peta kota Sidoarjo

https://www.google.com/maps

\section{METODE}

\section{a. Tujuan Persiapan}

Tahap persiapan dari kegiatan adalah melakukan koordinasi jadwal dan menyusun susunan acara dengan tim pengurus MGMP Biologi SMA Kabupaten Sidoarjo melalui alat komunikasi WhatsApp Group.

b. Tahap pelaksanaan

Kegiatan ini dilaksanakan secara daring menggunakan zoom. Peserta kegiatan ini adalah semua guru mata pelajaran Biologi yang tergabung di dalam MGMP Biologi SMA Kabupaten Sidoarjo. Materi yang disampaikan adalah jenis-jenis nyamuk di Indonesia, peranan di masyarakat sebagai vektor biologi, dan habitat perkembang biakan (breeding place) nyamuk. Instrumen yang digunakan adalah laptop, materi presentasi format ppt, zoom, dan google form. 


\section{c. Evaluasi}

Semua peserta mengerjakan pretest sebelum pemberian materi dan posttest setelah materi di aplikasi google form dalam waktu 5 menit. Ada 15 soal yang harus dijawab oleh peserta. Satu soal dikerjakan selama 20 detik. Data pertanyaan yang paling banyak dijawab dengan benar dan salah, nilai tertinggi, nilai terendah, dan nilai rata-rata MGMP Biologi diolah dan dianalisis secara deskriptif.

\section{HASIL DAN PEMBAHASAN}

Tim pengabdi telah melaksanakan pendidikan dan pelatihan (diklat) pada guru biologi, pada Senin, 25 Januari 2021 pada pukul 09.00-12.00 WIB melalui zoom. Kegiatan ini dihadiri oleh 42 orang guru Biologi SMA se-Sidoarjo. Latar belakang pendidikan peserta adalah pendidikan biologi (71\%), biologi murni (24\%), dan bukan keduanya (5\%) Para guru sangat antusias mengikuti kegiatan ini dari aktivitas menjawab soal, mengikuti materi, dan tanya jawab.

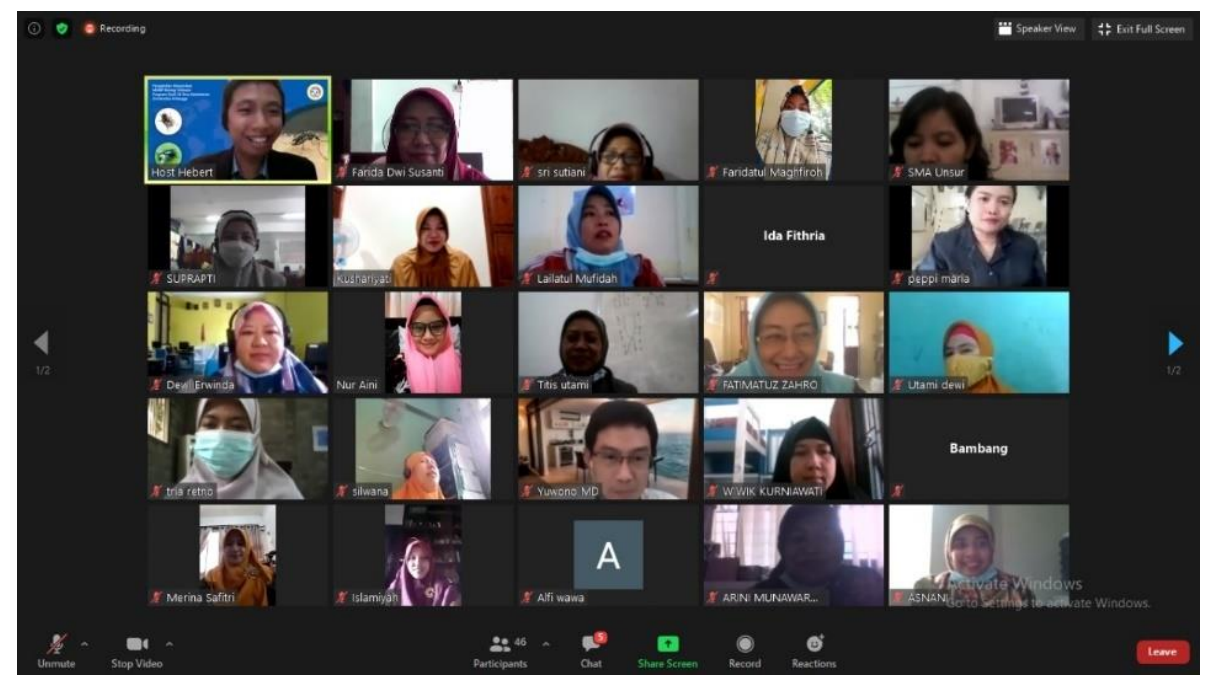

Gambar 1. Foto Peserta dan Tim Pengabdian Masyarakat

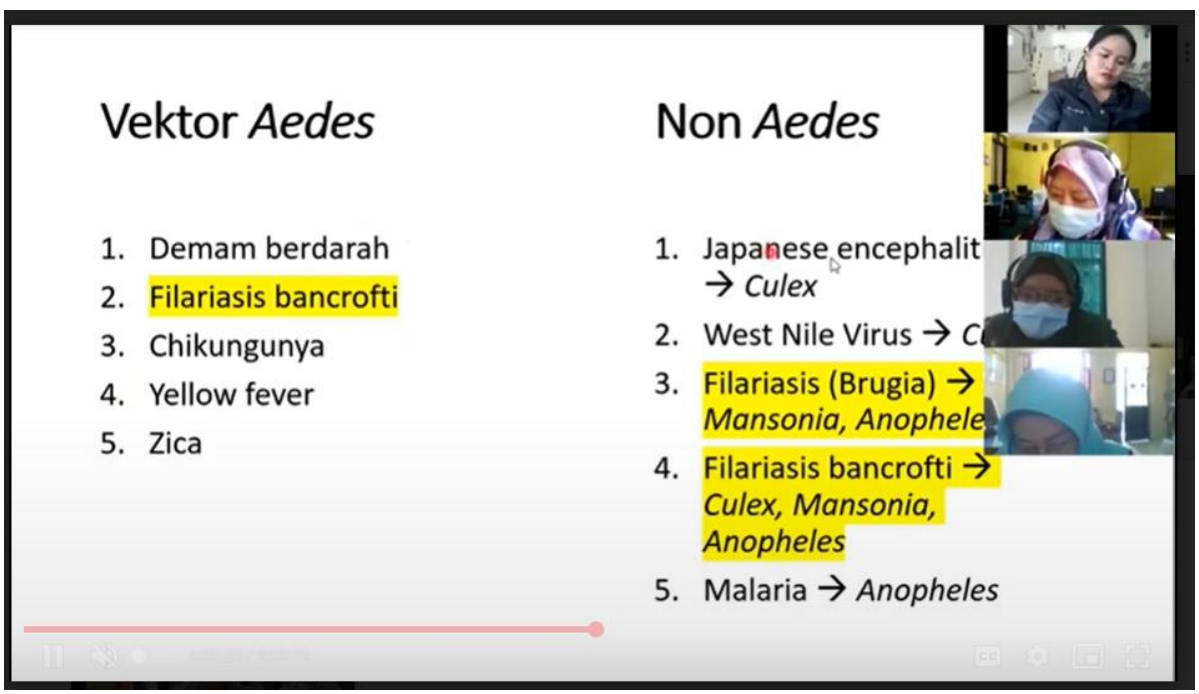

Gambar 2. Tim Pengabdian mempresentasikan materi nyamuk 
Secara umum, pengetahuan awal mula-mula (prior knowledge) peserta menjawab soal dengan benar pada pertanyaan disajikan pada Tabel 1. Lebih dari $50 \%$ peserta mampu menjawab 10 pertanyaan dengan benar. Pertanyaan "Ada di ordo manakah hewan nyamuk?" dapat dijawab benar oleh $88 \%$ peserta dan pertanyaan "Benar atau salah: Nyamuk Aedes adalah vektor demam berdarah" dapat dijawab benar oleh 93\% peserta. Peserta paling banyak salah (86\%) menjawab soal "Benar atau salah: Nyamuk Aedes adalah vektor filariasis (kaki gajah)". Ada miskonsepsi dari peserta termasuk buku pelajaran Biologi selama ini bahwa vektor filariasis (kaki gajah) adalah nyamuk Culex. Penyakit kaki gajah atau human lymphatic filariasis (LF) dapat ditransmisikan oleh banyak vektor nyamuk, seperti Anopheles, Culex, Aedes, Mansonia, dan Ochlerotatus (Famakinde, 2018; Adrianto, 2020).

Tabel 1. Profil pengetahuan awal peserta

\begin{tabular}{lcc}
\hline \multicolumn{1}{c}{ Soal pertanyaan } & Jawab benar & Jawab salah \\
\hline $\begin{array}{l}\text { Hewan nyamuk merupakan kelompok dari } \\
\text { filum apa? }\end{array}$ & $48 \%$ & $52 \%$ \\
\hline Ada di ordo manakah hewan nyamuk? & $88 \%$ & $12 \%$ \\
\hline $\begin{array}{l}\text { Manakah tempat bertelur dari nyamuk } \\
\text { Aedes aegypti? }\end{array}$ & $43 \%$ & $57 \%$ \\
\hline $\begin{array}{l}\text { Benar atau salah: Nyamuk Aedes adalah } \\
\text { vektor demam berdarah }\end{array}$ & $93 \%$ & $7 \%$ \\
\hline $\begin{array}{l}\text { Benar atau salah: Nyamuk Aedes adalah } \\
\text { vektor filariasis (kaki gajah) }\end{array}$ & $14 \%$ & $86 \%$ \\
\hline $\begin{array}{l}\text { Benar atau salah: Nyamuk Aedes adalah } \\
\text { vektor malaria }\end{array}$ & $69 \%$ & $31 \%$ \\
\hline $\begin{array}{l}\text { Benar atau salah: Nyamuk Aedes adalah } \\
\text { vektor japanese encephalitis (JE) }\end{array}$ & $60 \%$ & $40 \%$ \\
\hline $\begin{array}{l}\text { Benar atau salah: Nyamuk Aedes adalah } \\
\text { vektor chikungunya }\end{array}$ & $52 \%$ & $48 \%$ \\
\hline $\begin{array}{l}\text { Benar atau salah: Nyamuk Aedes adalah } \\
\text { vektor west nile virus }\end{array}$ & $57 \%$ & $43 \%$ \\
\hline $\begin{array}{l}\text { Benar atau salah: Di selokan dapat } \\
\text { dijumpai larva nyamuk Aedes aegypti }\end{array}$ & $55 \%$ & $45 \%$ \\
\hline $\begin{array}{l}\text { Manakah ciri khas habitat bertelur dan } \\
\text { tempat aktivitas nyamuk Aedes aegypti }\end{array}$ & $67 \%$ & $33 \%$ \\
\hline $\begin{array}{l}\text { Gambar spesies nyamuk Aedes apakah ini? } \\
\text { Jenis kelamin apakah nyamuk ini? }\end{array}$ & $55 \%$ & $45 \%$ \\
\hline $\begin{array}{l}\text { Gambar larva nyamuk apakah ini? } \\
\text { Manakah ciri khas siphon pada larva } \\
\text { Aedes? }\end{array}$ & $64 \%$ & $36 \%$ \\
\hline
\end{tabular}

Data tes peserta di awal dan di akhir kegiatan menunjukkan ada peningkatan pengetahuan peserta. Jumlah soal tes adalah 15 soal dengan nilai maksimal adalah 100. Rata-rata skor pre-test dari peserta adalah 53, dengan nilai tertinggi 87 dan nilai terendah 13. Ini mirip dengan laporan Roziqin dkk (2020) dimana pengetahuan peserta paling rendah $50 \%$ dan paling tinggi $75 \%$. Untuk rata-rata skor post-test dari peserta adalah 81 , dengan nilai tertinggi adalah 100 dan nilai terendah 40. Dari hasil post-test 
didapatkan bahwa sebagian besar peserta sudah memahami morfologi, habitat, dan peran vektor. Temuan ini mirip dengan laporan Roziqin dkk (2020) bahwa pemahaman dan kemampuan menjawab oleh peserta meningkat setelah mendapatkan sosialisasi dibandingkan sebelum sosialisasi.

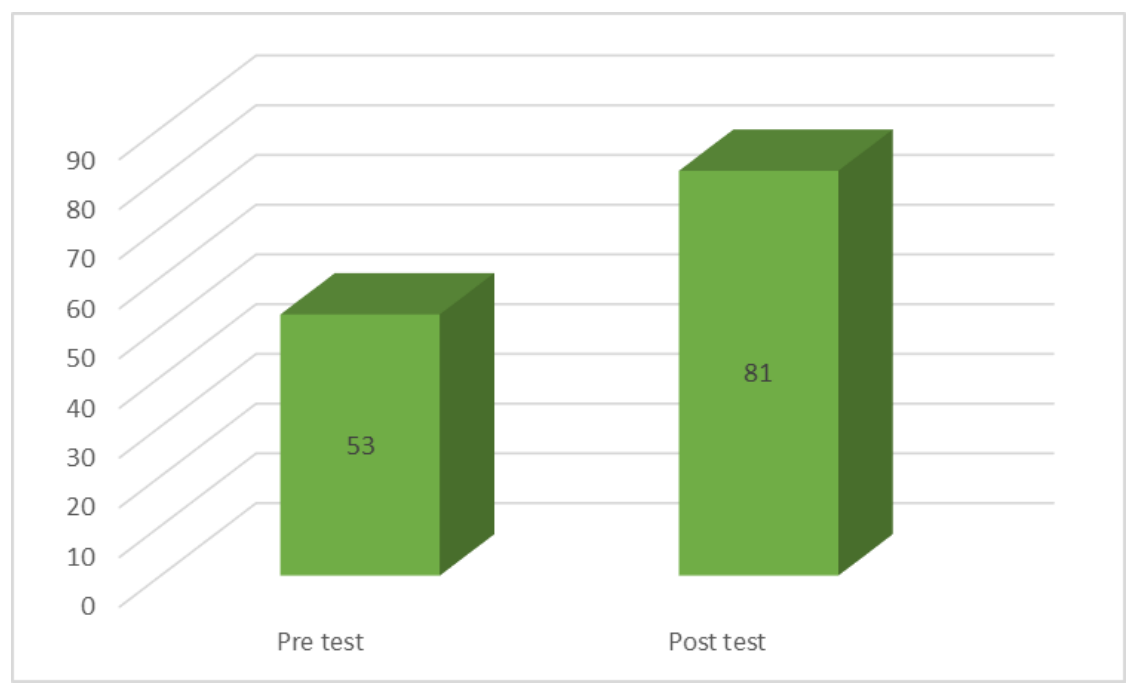

Gambar 3. Grafik peningkatan pengetahuan peserta

Ke depannya, para guru biologi Sekolah Menengah Atas (SMA) perlu mendapatkan pembekalan materi nyamuk, khususnya pengendalian nyamuk karena dari penelusuran laporan penelitian maupun pengabdian masyarakat, kegiatan sosialisasi pengendalian nyamuk lebih banyak diberikan kepada guru SD. Terlebih lagi diperkuat laporan oleh Hendri dkk (2020) bahwa pengetahuan pengendalian nyamuk pada siswa SMA masih kurang baik $(97,50 \%)$.

\section{KESIMPULAN}

Kegiatan pengabdian masyarakat telah berjalan dengan lancar. Hasil pre test dan post test menunjukkan ada peningkatan pengetahuan dari para peserta dari rata-rata nilai 53 menjadi 81. Kompetensi ini sangat berguna untuk membantu para guru mengajar biologi topik virus, protista, dan animalia.

\section{DAFTAR PUSTAKA}

Adrianto, H. (2020). Buku Ajar Parasitologi. Jogjakarta: Rapha Publishing. Adrianto, H. (2021). Fitotelmata: Tempat Perindukan Nyamuk Terabaikan Selama Pandemi COVID-19. Jurnal Enviscience, 5(1), 25-32. https://doi.org/10.30736/5ijev.v5iss1.249.

Famakinde, D. O. (2018). Mosquitoes and the Lymphatic Filarial Parasites: Research Trends and Budding Roadmaps to Future Disease Eradication. Tropical Medicine and Infectious Disease, 3(1), 4. https: / / doi.org/10.3390/tropicalmed3010004.

Harapan, H., Michie, A., Mudatsir, M., Sasmono, R. T., \& Imrie, A. (2019). Epidemiology of Dengue Hemorrhagic Fever in Indonesia: Analysis of Five Decades Data from The National Disease Surveillance. BMC 
Research Notes, 12(1), 350. https://doi.org/10.1186/s13104-0194379-9

Hendri, J., Prasetyowati, H., Hodijah, D.N., Sulaeman, R.P. (2020). Pengetahuan Demam Berdarah Dengue pada Siswa di Berbagai Level Pendidikan Wilayah Pangandaran. Aspirator, 12(1), pp 55-64. https://doi.org/10.22435/asp.v12i1.283

Kemenkes. (2019). Upaya Pencegahan DBD dengan 3M Plus. Diakses dari laman https://promkes.kemkes.go.id/upaya-pencegahan-dbddengan-3m-plus pada tanggal 10 Juni 2021.

Kemenkes. (2020). Rencana Aksi Program Direktorat Jenderal Pencegahan dan Pengendalian Penyakit tahun 2020-2024.

Lorenz C, Azevedo TS, \& Chiaravalloti-Neto F. (2020). COVID-19 and Dengue Fever: A Dangerous Combination for The Health System in Brazil. Travel Medicine and Infectious Disease, 35(January), pp. 1-2. https://doi.org/https://doi.org/10.1016/j.tmaid.2020.101659.

Pramadani, A.T., Hadi, U.K., Satrija, F. (2020). Habitat Aedes aegypti dan Aedes albopictus sebagai Vektor Potensial Demam Berdarah Dengue di Kecamatan Ranomeeto Barat, Provinsi Sulawesi Tenggara. Aspirator 12(2), pp. 123 - 136. https://doi.org/10.22435/asp.v12i2.3269

Pramestuti, N., Djati AP. (2013). Distribusi Vektor Demam Berdarah Dengue (DBD) Daerah Perkotaan dan Perdesaan di Kabupaten Banjarnegara. Bul Penelit Kesehat. 41(3):163-70

Prayitno, A., Taurel, A. F., Nealon, J., Satari, H. I., Karyanti, M. R., Sekartini, R., Soedjatmiko, S., Gunardi, H., Medise, B. E., Sasmono, R. T., Simmerman, J. M., Bouckenooghe, A., \& Hadinegoro, S. R. (2017). Dengue Seroprevalence and Force of Primary Infection in A Representative Population of Urban Dwelling Indonesian Children. PLoS neglected tropical diseases, 11(6), e0005621. https: / / doi.org/10.1371/journal.pntd.0005621

Roziqin, A., Nuryady, M. M., Fauzi, A., \& Setyaningrum, Y. (2020). Sosialisasi Pencegahan Demam Berdarah Dengue (DBD) Melalui Pelatihan Pembuatan Ovitrap Pada Masa Pandemi di SMP Muhammadiyah 1 Malang. Sasambo: Jurnal Abdimas (Journal of Community Service), 2(3), 209-216. https://doi.org/10.36312/sasambo.v2i3.312. 